failures of the NHS that the various professional groups have remained primarily in their tribes (not least in their reading habits), and we want this to be a journal that will be useful to all groups.

Audit Specialist and Respiratory Physician and
Editor of Quality in Health Care,

FIONA MOSS

Central Middlesex Hospital, London NW10 7NS

Editor, $B M \mathcal{F}$
1 Department of Health. Medical audit in the hospital and community health services. London: DoH 1991. ( $\mathrm{HC}(91) 2$

2 Department of Health. Medical audit in the family practitioner services. London: DoH, 1990 $(\mathrm{FP})(90) 8$

3 Lyons C, Gumpert R. Medical audit data: counting is not enough. B.MF 1990;300:1563-6.

4 Smith T. Medical audit. BMF 1990;300:65.

5 Nixon SJ. Defining essential hospital data. BMF 1990;300:380-1.

6 Bell D, Layton AJ, Gabbay J. Use of a guideline based questionnaire to audit hospital care of acute asthma. BMF 1991;302:1440-3.

7 Berwick DM. Continuous improvement as an ideal in health care. N Engl f. Med 1989;320:53-6. 8 Berwick DM, Godfrey AB, Roessner J. Curing health care: new' strategies for quality improzement. San Francisco: Jossey-Bass, 1991

9 Irvine D. Managing for quality in general practice. London: King's Fund Centre, 1990.

10 Smith R. Medicine's need for kaizen. BM7 1990;301:679-80.

\title{
Is rheumatoid arthritis an infectious disease?
}

\author{
An epidemic would answer the question
}

Unlike most common chronic diseases, little is known about the aetiology of rheumatoid arthritis. Given the concordance rate in monozygotic (identical) twins, any genetic component is unlikely to be greater than $30 \%,{ }^{12}$ and no obvious environmental factors exist to explain the remaining $70 \%$. A viral cause seems the most likely. Infections with viruses, such as parvovirus, ${ }^{3}$ result in inflammatory polyarthritides indistinguishable from rheumatoid arthritis, but seroepidemiological and other studies have failed to confirm a role for parvovirus or, indeed, other viruses in series of patients with rheumatoid arthritis. ${ }^{4-6}$ The identification of Borrelia burgdorferi as the causative agent for Lyme disease, ${ }^{7}$ which was initially considered to be an epidemic form of juvenile rheumatoid arthritis, accelerated the search for a microbiological cause for adult rheumatoid arthritis.

Unlike Lyme arthritis, no clusters of rheumatoid arthritis have been reported. Indeed, in familial clusters - in which a shared environmental insult might be expected to play a part - the calendar year of onset of disease in affected sibling pairs agreed no more often than in pairs of sporadic cases. ${ }^{9} 10$ No geographically defined populations exist with an exceptionally high incidence of the disease. Rheumatoid arthritis is rare in rural dwelling South African black people ${ }^{11-13}$ compared with urban dwellers. ${ }^{14}$ Urbanisation, being a proxy for overcrowding and perhaps for greater exposure to infectious diseases, may therefore be a risk factor.

The most striking observation about the geographic distribution of rheumatoid arthritis, however, is the similar prevalences reported in many different populations despite the diverse methods used. ${ }^{15}$ Few organisms, with the notable exception of Epstein-Barr virus, are sufficiently ubiquitous to explain this geographic pattern. Possibly relevant is the similar geographic distributions of rheumatoid arthritis and infectious mononucleosis. ${ }^{16}$

A potentially more rewarding line of inquiry has been the search for time trends in a population. The evidence suggests that rheumatoid arthritis has been declining in both incidence and severity. ${ }^{17} 18$ Thus population based studies of cases in both the United States ${ }^{1920}$ and the United Kingdom ${ }^{21}$ support a decline in incidence in the past 25 years, mirroring the anecdotal impression of rheumatologists. ${ }^{23}$ Similarly anecdotal evidence exists for a decline in severity-for example, as judged by the occurrence of vasculitis ${ }^{2+}$ - though data are limited. Successive generations of patients with rheumatoid arthritis seem increasingly less likely to be positive for rheumatoid factor or to have erosive disease or subcutaneous nodules. ${ }^{25}$ Mortality, particularly in older women, may be declining, ${ }^{26}$ though whether this reflects trends in incidence, severity, or certifying death is unclear. More persuasive is the direct observation that follow up of similarly composed groups of patients has shown a fall in the rate of those progressing to severe handicap over the past 25 years. ${ }^{2327}$

These observations are obviously compatible with several explanations. The decline in severity could be explained by more effective treatment, although limited evidence exists for any of the currently available treatments improving the long term prognosis sufficiently to have an impact on populations. The apparent decline in incidence could be due to changes in diagnostic practice with the application of more rigid criteria. Such a phenomenon, however, would not be consistent with any decline in severity.

Twenty years ago it was postulated that the improvement in atmospheric pollution, perhaps mediated by a reduction in the incidence of respiratory infections, was responsible for the reduction in the prevalence of rheumatoid factor in the population. ${ }^{28}$ Others have argued more recently that the temporal patterns of rheumatoid arthritis are consistent with a similar cyclic change in the epidemicity and virulence of specific, but as yet unknown, micro-organisms. ${ }^{2429}$ The conclusion remains that a viral cause for rheumatoid arthritis in genetically susceptible people is the strongest candidate. In the absence of further leads from the laboratory all epidemiologists can do is wait with their bags packed for the call to investigate an apparent epidemic.

\section{Director,}

ALAN J SILMAN

ARC Epidemiology Research Unit,

Stopford Building,

University of Manchester,

Manchester M13 9PT

Lawrence JS. Rheumatoid arthritis - nature or nurture? Ann Rheum Dis 1970;29:357-79.

2 Aho K, Koskenvuo M, Tuominen J, Kaprio J. Occurrence of rheumatoid arthritis in a nationwide series of twins. F Rheumatol 1986;13:899-902.

3 Naides SJ, Scharosch LL, Foto F, Howard EJ. Rheumatologic manifestations of human parvovirus B19 infection in adults. Arthritis Rheum 1990;33:1297-309.

4 Cohen BJ, Buckley MM, Clewley JP, Jones VE, Puttick AH, Jacoby RK, et al. Human parvovirus infection in early rheumatoid and inflammatory arthritis. Ann Rheum Dis 1986;45:832-8.

5 Ferrell PB, Aitchesion CT, Pearson GR, Tan EM. Seroepidemiological study of relationships between Epstein-Barr virus and rheumatoid arthritis. $\mathcal{F}$ Clin Invest 1981;67:681-7.

6 Venables PJW, Ross MGR, Charles PJ, Melsom RD, Griffiths PD, Maini RN, et al. A seroepidemiological study of cytomegalovirus and Epstein-Barr virus in rheumatoid arthritis and sicca syndrome. Ann Rheum Dis 1985;44:742-6.

7 Steere AC, Grodzicki RL, Kornblatt AN, Craft JE, Barbour AG, Burgdorfer W, et al. The spirochetal etiology of Lyme disease. N Engl F Med 1983;308:733-9.

8 Steere AC, Malawista SE, Hardin JA, Snydman DR, Chope RE, Andiman WA, et al. An epidemic of oligoarticular arthritis in children and adults in three Connecticut communities. Arthritis Rheum 1977;20:7-37.

9 Silman AJ, Ollier WER, Currey HLF. Failure to find disease similarity in sibling pairs with rheumatoid arthritis. Ann Rheum Dis 1987;46:135-8.

0 Sanders PA, Grennan DM. Age and year of onset differences in siblings with rheumatoid arthritis. Br J Rheumatol 1990;29:128-30.

11 Beighton P, Soloman L, Valkenburg HA. Rheumatoid arthritis in a rural South African negro population. Ann Rheum Dis 1975;34:136-41.

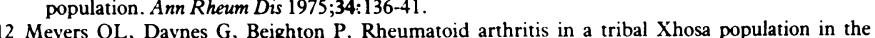
Transke. Ann Rheum Dis 1977;36:62-5.

13 Brighton SW, de la Harpe AL, van Staden DJ, Badenhorst JH, Myers OL. The prevalence of rheumatoid arthritis in a rural African population. $\mathcal{F}$ Rheumatol 1988;15:405-8.

rheumatoid arthritis in a rural African population. $\mathcal{F}$ Rheumatol 1988;15:405-8.
Soloman L, Robin G, Valkenburg HA. Rheumatoid arthritis in an urban South African negro Soloman L, Robin G, Valkenburg HA. Rheurat
population. Ann Rheum Dis 1975;34:128-35.

15 Spector TD. Rheumatoid arthritis. Rheum Dis Clin North Am 1990;16:513-37. 
16 Vaughan JH, Carson DA, Fox RI. The Epstein-Barr virus and rheumatoid arthritis. Clin Exp Rheumatol 1983;1:265-72.

17 Silman AJ. Recent trends in rheumatoid arthritis. Br f Rheumatol 1986;25:328-9.

18 Silman AJ. Are there secular trends in the occurrence and severity of rheumatoid arthritis? Scand $\mathcal{\gamma}$ Rheumatol 1989;79:25-30

19 Linos A, Worthington JW, O'Fallon M, Kurland LT. The epidemiology of rheumatoid arthritis in Rochester Minnesota: a study of incidence, prevalence, and mortality. Am $\mathcal{F}$ Epidemio Rochester Minnes: $111: 87-98$.

20 Dugowson CE, Bley L, Koepsell TD, Nelson JL, Daling JR. Incidence of rheumatoid arthritis in women. Arthritis Rheum 1989;22(suppl):A83.

21 Silman AJ. Has the incidence of rheumatoid arthritis declined in the United Kingdom? $\mathrm{Br}$ Rheumatol 1988;37:77-8.

22 Hochberg M. Changes in the incidence and prevalence of rheumatoid arthritis in England an Wales-1970-1982. Semin Arthritis Rheum 1990;5:294-302.
23 Laurent R, Robinson RG, Beller EM, Buchanan WW. Incidence and severity of rheumatoid arthritis - the view from Australasia. Brf Rheumatol 1989;28:360-1.

24 Buchanan WW, Laurent RM. Rheumatoid arthritis: an example of ecological succession. Canadian Bulletin of Medical History 1990;7:77-91.

25 Silman AJ, Davies P Currey HLF, Evans SJW. Is rheumatoid arthritis becoming less severe? fournal of Chronic Diseases 1983:36:891-7.

Jounal of Chrom Diseases 1

A. Australian mortality statistics for rheumatoid arthritis 1950-81 analysis of death certificate data. Ann Rheum Dis 1988;47:563-9.

27 Aho $\mathrm{K}$, Kirpila J, Wager $\mathrm{O}$. The persistence of the agglutination activation factor (AAF) in the circulation. A nine year study of twenty seven patients. Annals of Experimental Medicin 1959;37:377-8

28 Lawrence JS. Rheumatism in populations. London: Heinmann, 1977.

29 Buchanan WW, Murdoch RM. That rheumatoid arthritis will disappear. F Rheumatol 1979;6: $324-9$.

\section{"Second line" drugs for rheumatoid arthritis}

\section{The next generation of drugs needs more rigorous assessment}

As its cause is unknown rheumatoid arthritis is difficult to treat. The bulwark of drug treatment remains symptomatic relief with non-steroidal anti-inflammatory drugs and attempts at suppressing the disease process with "second line" or "disease modifying" drugs," including gold salts (first introduced in 1929) ${ }^{2}$; steroids $(1949)^{3}$; chloroquine $(1956)^{4}$; penicillamine $(1973)^{5}$; sulphasalazine $(1980)^{6}$; auranofin $(1982)^{7}$; and cytotoxic drugs such as cyclophosphamide, azathioprine, and methotrexate. ${ }^{89}$ Does use of these drugs, either singly or in combination, alter the prognosis of rheumatoid arthritis?

Evaluating the effects of second line drugs in a disease that is subject to relapses and remissions is difficult especially when they provide symptomatic relief and have uncertain effects on the underlying disease process. Rheumatologists use measures of disease process and outcome to evaluate the effects of second line drugs ${ }^{10}:$ measures of process consist of variables such as the erythrocyte sedimentation rate, $\mathrm{C}$ reactive protein concentration, and titres of rheumatoid factor; measures of outcome encompass various functional indices (for example, the health assessment questionnaire ${ }^{11}$ ) and radiological progression of joint damage. An important problem with these two modes of measurement is the generally poor correlation between them. Other problems are that most clinical trials monitor changes over one to two years - a relatively short time in the lifetime of the diseaseand the high drop out rate of patients being maintained with second line treatment - less than one third will still be taking their drugs two years on. ${ }^{12}$

Many published trials of second line treatment in rheumatoid arthritis have too few patients to be meaningful, a problem that can be overcome by meta-analysis. Using this approach, Clark and her colleagues have shown that over six months injectable gold improved the active joint count, functional capacity, and erythrocyte sedimentation rate by $13-30 \% .{ }^{13}$ The most common side effect was dermatitis (15\%); proteinuria occurred in only $0.7 \%$. Using a similar approach, Iannuzzi et al concluded that in 17 trials suitable for analysis only injectable gold and cyclophosphamide convincingly retarded radiological progression of disease. ${ }^{14}$ More recent data, however, suggest that sulphasalazine may also slow the appearance of new joint erosions. ${ }^{15}$ Using meta-analysis, Felson et al compared the efficacy and toxicity of six second line drugs and concluded that, apart from auranofin and antimalarials, which had a weaker effect, no significant difference existed between the efficacies of sodium aurothiomalate, penicillamine, methotrexate, and sulphasalazine. ${ }^{16}$ (Sodium aurothiomalate, however, was more toxic.) Overall, nearly one in three patients had dropped out of the trials analysed. The authors commented that at least 170 patients are required in each treatment group to give sufficient power to differentiate one second line drug from another.

What about newer treatments? Cyclosporin $\mathrm{A}$ has been fashionable, but an 18 month follow up study of 16 patients found that long term loss of renal function occurred and radiological progression was not halted. ${ }^{17} \mathrm{~A}$ recent symposium in the United States challenged the traditional therapeutic "pyramid" in rheumatoid arthritis (a base beginning with non-steroidal anti-inflammatory drugs and progressing through second line drugs to cytotoxic agents at the apex), with several participants advocating the relatively early use of combination treatment with methotrexate, gold, azathioprine, and cyclophosphamide in various permutations. ${ }^{18}$ The cost: benefit ratio of such an approach, however, may be high, and so far too few patients have been treated to establish whether combination treatment is better than the pyramid regimen. Immunotherapy with monoclonal antibodies to $T$ cell subsets and the use of cytokine inhibitors may be an advance, ${ }^{19}$ but carefully designed trials with sufficient numbers of patients, clearly defined end points, and reasonably long treatment will be required if we are to avoid the pitfalls of the past two decades of antirheumatoid treatment.

Professor of Rheumatology,

R D STURROCK

University Department of Medicine,

Centre for Rheumatoid Diseases,

Royal Infirmary, Glasgow G31 2ER

1 Hepburn B. What is a disease modifying antirheumatoid drug? $f$ Rheumatol 1986;15(suppl 16): 40-2.

2 Forestier J. L'Aurotherapies dans les rheumations chroniques. Bulletins et Memoires de la Societe Medicale des Hopitaux de Paris 1929;44:323.

3 Hench PS, Kendall EC, Slocumb CH, Polly HF. The effect of a hormone of the adrenal cortex (17hydroxy-11 dehydrocortisone: compound $\mathrm{E}$ ) and of pituitary adrenocorticotrophic hormone on rheumatoid arthritis. Preliminary report. Proceedings of the Staff Meetings of the Mayo Clinic 1949;24:181-97.

4 Freedman A. Chloroquine and rheumatoid arthritis. A short-term controlled trial. Ann Rheum Dis 1956;15:241-56.

Multicentre Trial Group. Controlled trial of D-penicillamine in rheumatoid arthritis. Lancet 1973;i:275-80.

6 McCarthy B, Amos R, Durham S, et al. Sulphasalazine in rheumatoid arthritis. BMJ 1980;280 442-4.

7 Katz WA, Alexander S, Bland JH, et al. The efficacy and safety of auranofin compared to placebo in rheumatoid arthritis. F Rheumatol 1989;9(suppl 8):173-8.

8 Luqhami RA, Palmer RG, Bacon BA. In: Brookes PM, ed. Slow-acting antirheumatic drugs and immunosuppressives. London: Baillière Tindall, 1990:595-619.

Tugwell P, Bennette K, Gent $M$. Methotrexate in rheumatoid arthritis. Ann Intern Med 1987; 107:358-66.

10 Scott DL, Dacre JE, Greenwood A, Treasure L, Huskisson EC. Can we develop simple response criteria for slow acting antirheumatoid drugs? Ann Rheum Dis 1990;49:196-8.

11 Fries JF, Spitz P, Kraines RG, Holman HR. Measurement of patient outcome in arthritis. Arthritis Rheum 1980;23:137-45

12 Thompson PW, Kirwan JR, Barnes CG. Practical results of treatment with disease-modifying antirheumatoid drugs. Brf R Reumatol 1985;24:167-75.

Clark P, Tugwell P, Bennett K, Bombardier C. Meta-analysis of injectable gold in RA. $\mathcal{F}$ Rheumatol 1989;16:442-7.

14 Iannuzzi L, Dawson N, Zein N. Does drug therapy slow radiographic deterioration in rheumatoid arthritis. N Engl F Med 1983;309:1023-8.

15 Pullar T, Hunter J, Capell HA. Effect of sulphasalazine on the radiological progression of rheumatoid arthritis. Ann Rheum Dis 1987;46:398-402.

16 Felson D, Anderson J, Meenan R. The comparative efficacy and toxicity of second-line drugs in rheumatoid arthritis. Anthritis Rheum 1990;33:1449-61.

rheumatoid arthritis. Arthritis Rheum 1990;33:1449-61.
7 Van Rythoven AW, Dysmans B, The HSG. Long term cyclosporine therapy in RA. I Rheumatol 1991;18:19-23.

18 Jaffe IA. Combination therapy of RA-rationale and overview. I Rheumatol 1990;17(suppl 25): 24-7.

19 Panayi GS, Lanchbury JSS, Kingsley G, eds. First international symposium on the immunotherapy of the rheumatoid diseases. Brf Rheumatol 1991;30(suppl 2):3-9. 